\title{
Involvement of proinflammatory S100A9/A8 in the atherocalcinosis of aortic valves
}

\author{
R. A. Moskalenko ${ }^{1}$, A. M. Romaniuk ${ }^{1}$, I. O. lashchishyn ${ }^{1,2}$, I.-M. S. Zakorko ${ }^{1}$, \\ A. M. Piddubnyi ${ }^{1}$, Ye. O. Chernov $^{2}$, L. 0. Morozova-Roche ${ }^{2}$ \\ ${ }^{1}$ Sumy State University, Ukraine, ${ }^{2}$ Umeå University, Sweden
}

According to the results of the Euro-Heart Survey on Vascular Heart Disease the most common pathology is nonrheumatic aortic stenosis, it is also called as calcific aortic valve stenosis (CAVS), as in its pathogenesis the process of biomineralization of valve cusps and ring plays the main role.

The aim of the work is the immunohistochemical study of mineralized tissue of aortic heart valves, which are affected by atherocalcinosis.

Materials and methods. 30 samples of mineralized aortic valves (I group) and 10 samples of aortic valve without evidence of biomineralization (II group - control) were studied. Immunohistochemical study of expression of collagen (Collagen I), CD68, myeloperoxidase (MPO), calgranulin A (S100A8), calgranulin B (S100A9), caspase 3 (Casp 3) and osteopontin (OPN) was conducted in AV tissue of both groups.

Results. In CAV tissues the fibrillar component (collagen I) growths was found, but the quantitative and qualitative compositions of CD68+ circulating inflammatory cells are not significantly different from the control group. CAVs contain much more MPO+-cells $(p<0.001)$ in comparison to the group of AVs without biomineralization.

Our data show a significant increase of the S100A9 and OPN expression in the mineralized tissue of AVs $(p<0.01)$. Also, a higher expression level of Casp3 and MPO was found in CAVs $(p<0.05)$. Comparing the first and the second groups of AVs connection between the expression of S100A8 was not determined.

Conclusion. High Casp 3 expression confirms the increased level of cell elimination in the CAVs tissue, which is obviously connected with the impact of high local concentrations of S100A9. These facts can contribute to the development of pathological biomineralization of AV. Since osteopontin inhibits the hydroxyapatite formation by binding to the surface of the crystals, its hyperproduction is a counteracting factor against biomineralization in AV tissue.

\section{Участь прозапальних бікків S100A9/A8 у атерокальцинозі аортальних киапанів}

\section{Р. А. Москаленко, А. М. Романюк, І. О. Ящишин, І.-М. С. Закорко, А. М. Піддубний, Є. О. Чернов, А. О. Морозова-Роше}

Згідно з результатами Європейського дослідження серцевих вад (Euro-Heart Survey on Vascular Heart Disease), серед уражень серцевих клапанів найпоширенішою патологією $€$ неревматичний аортальний стеноз, який також називають кальцифрікованим аортальним стенозом (КАС), бо у його патогенезі головна роль належить процесу біомінералізації стулок і кільця клапана. Демографрічно-зумовлене зростання кількості людей старших вікових груп призводить до збільшення дегенеративно-метаболічних захворювань серцевих аортальних клапанів (АК), особливо спричинене атеросклеротичними процесами.

Мета роботи - імуногістохімічне дослідження мінералізованих тканин аортальних серцевих клапанів, що уражені атерокальцинозом.

Матеріали та методи. Усього дослідили 30 зразків мінералізованих аортальних клапанів (I група) та 10 зразків аортальних клапанів без ознак біомінералізації (II група), які виступали як контроль. У тканині АК обох груп здійснили імуногістохімічне дослідження експресії колагену I (Collagen I), CD68, мієлопероксидази (MPO), кальгрануліну A (S100A8), кальгрануліну B (S100A9), каспази 3 (Casp 3) та остеопонтину (OPN). Оцінювання статистичної вірогідності різниці результатів між групами зразків проводили за допомогою непараметричного критерію Манна-Уітні. Результати вважали статистично вірогідними при ступені вірогідності понад $95 \%$ ( $<<0,05)$.

Результати. У тканині CAV виявлено розростання фібрилярного компонента (колаген I), але кількісний та якісний склад CD68+ циркулюючих запальних клітин істотно не відрізняється від контрольної групи АК. Кальцифіковані АК містять більше МРО+ клітин $(p<0.001)$ порівняно з групою АК без біомінералізації.

Наші дані показують значуще підвищення експресії S100A9 і ОПН у тканині мінералізованих AK ( $<<0,01)$. Taкож у CAV виявлений вищий рівень експресії Casp3 ( $<<0,05)$. Порівнюючи I та II групи АК, не виявлено зв'язку між експресією S100A8.

Висновки. Висока експресія Casp3 підтверджує підвищений рівень елімінації клітин у тканині CAV, що, очевидно, пов'язано із впливом високої місцевої концентрації S100A9. Ці фракти можуть сприяти розвитку патологічної біомінералізації АК. Оскільки остеопонтин інгібує утворення гідроксиапатиту, зв'язуючись з поверхнею кристалів, то його гіперпродукція у тканинах АК є фрактором протидії біомінералізації. 
Кмючевые слова: аортальный клапан, кальгранулин А, кальганулин В.

Патология. - 2017. -

T. 14, № 1(39). -

C. $49-56$

\title{
Участие провоспалительных белков S100A9/A8 в атерокальцинозе аортальных киапанов
}

\author{
Р. А. Москаленко, А. Н. Романюк, И. А. Ящишин, И.-М. С. Закорко, А. М. Пиддубный,
} Е. А. Чернов, А. А. Морозова-Роше

Согласно результатам Европейского исследования сердечных пороков (Euro-Heart Survey on Vascular Heart Disease), среди поражений сердечных клапанов наиболее распространённой патологией является неревматический аортальный стеноз. Это заболевание также называют кальцифицированным аортальным стенозом (КАС), так как в его патогенезе главная роль принадлежит процессу биоминерализации створок и кольца клапана. Демографически-обусловленный рост числа людей старших возрастных групп приводит к увеличению дегенеративно-метаболических заболеваний сердечных аортальных клапанов (АК), особенно вызванных атеросклеротическими процессами.

Цель работы - иммуногистохимическое исследование минерализованных тканей аортальных сердечных клапанов, поражённых атерокальцинозом.

Материалы и методы. Всего было исследовано 30 образцов минерализованных аортальных клапанов (I группа) и 10 образцов аортальных клапанов без признаков биоминерализации (II группа), которые выступали в качестве контроля. В ткани АК обеих групп было проведено иммуногистохимическое исследование экспрессии коллагена I (Collagen I), CD68, миелопероксидазы (MPO), кальгранулина A (S100A8), кальгранулина B (S100A9), каспазы 3 (Casp 3) и остеопонтина (OPN). Оценку статистической достоверности разницы результатов между группами образцов проводили с помощью непараметрического критерия Манна-Уитни. Результаты считали статистически достоверными при степени достоверности более $95 \%(p<0,05)$.

Результаты. В ткани кальцифицированных АК обнаружено разрастание фибриллярного компонента (коллаген I), но количественный и качественный состав CD68+ циркулирующих воспалительных клеток существенно не отличается от контрольной группы АК. Кальцифицированные АК содержат больше MPO+ клеток ( $<<0.001)$ по сравнению с группой АК без биоминерализации. Наши данные показывают значимое повышение экспрессии S100A9 и OPN в ткани минерализованных AK $(p<0,01)$. Также в CAV выявлен более высокий уровень экспрессии Casp3 $(p<0,05)$. Сравнивая I и II группы АК, не обнаружили связи между экспрессией S100A8.

Выводы. Высокая экспрессия Casp3 подтверждает повышенный уровень элиминации клеток в ткани кальцифицированных АК, что, очевидно, связано с влиянием высокой местной концентрации S100A9. Эти фракты могут способствовать развитию патологической биоминерализации АК. Поскольку остеопонтин ингибирует образование гидроксиапатита, связываясь с поверхностью кристаллов, то его гиперпродукция в тканях АК является фактором противодействия биоминерализации.

During recent years in Europe and in Ukraine an increase of the prevalence of non-rheumatic valve affection can be observed, this relates to the growing of population in the elder age groups. This has led to the increase of the number of patients with non-rheumatic valve affection: they get older, have signs of coronary heart disease and engorgement heart failure more often, they had surgery on myocardial revascularization, diabetes type II and chronic renal failure [1,2]. According to the results of the Euro-Heart Survey on Vascular Heart Disease degenerative etiology dominated on aortic stenosis $(81.9 \%)$ for mitral $(61.3 \%)$ and aortic (50.3\%) failure. Only in the case of mitral stenosis rheumatological reasons play the main role $(85.4 \%)[1,3]$. The most common pathology is a non-rheumatic aortic stenosis, also called calcific aortic valve stenosis (CAVS), since biomineralization process of cusps and valve rings plays the main role in its pathogenesis [4]. In addition, the average age of patients with CAVS is higher than in cases of other valve diseases. Thus demographically-caused increase of degenerative and metabolic diseases leads to growing part of valve calcification.

The stage of mineralization of the aortic valve is assessed by echocardiography: I stage of calcification corresponds to the focal deposits of calcium compounds in the cusps and commissures; II stage - rough calcification of the AV cusps and commissures, which does not spread to the areas of cusps bonding; III stage - massive deposits of calcifications with the spread to the fibrous valve ring, aorta and the output of the left ventricle, the anterior cusp of the mitral valve [5].

Recent studies show the important role of the innate immunity receptors Toll-like receptors 2 (TLR2) and TLR4 in the CAVS development. Thus, expression of TLR2 and TLR4 causes the osteogenic phenotypic changes in interstitial cells of AV [6]. Involvement of (TLR2) and TLR4 in the processes of biomineralization draws attention to the agonist of these receptors - calprotectin complex [S100A8/ S100A9], which consists of calgranulin A (S100A8) and calgranulin B (S100A9) [7].

In recent works an important role of osteopontin was described. Osteopontin is a pro-inflammatory multifunctional cytokine and it is a perspective marker of the presence and the stage of AV mineralization [8].

The aim of the work is the immunohistochemical study of aortic heart valve tissue in the case of atherocalcinosis.

This article focuses on the elevated expression of S100A9 (calgranuline B) as a major inductive factor of vascular calcification and osteopontin as an inducible inhibitor of vascular calcification, and on our current understanding of their effects.

\section{Materials and methods}

Ethics committee protocol. Study conducting was approved by the ethics committee of the Medical Institute of Sumy State University (Proceedings № 3/6, 07/06/16). 
Sample collection. Sectional study was conducted on the materials, which were obtained during autopsy at Sumy Regional Pathological Office. Heart valves with the signs of atherosclerotic affection and biomineralization were selected for the study. Totally 30 calcific aortic valves (CAV) and $10 \mathrm{AV}$ with the signs of atherosclerotic changes, but without evident pathologic biomineralization (control group) were studied. AVs from the patients with endocarditis, rheumatic heart disease or bicuspid valves were excluded.

Immunohistochemistry. The aortic valve tissue samples were dewaxed in xylene and they were dehydrated during ethanol series. After deparaffinization sections were liable to the demasking of antigens during the thermal method by sections heating in the citrate buffer $(\mathrm{pH} \mathrm{6.0)}$ at the temperature of $95-98^{\circ} \mathrm{C}$. Diaminobenzidine (DAB) and amino-ethylcarbazol (AEC) were used as chromogen. The $4 \mu \mathrm{m}$-thick paraffin sections were sequentially incubated in $3 \% \mathrm{H}_{2} \mathrm{O}_{2}$ to remove endogenous peroxidase (10 min), washed in Tris-buffered saline Tween and incubated with $5 \%$ normal horse serum to block non-specific background staining (30 min). Tissue sections were incubated during 1 hour at room temperature with primary antibodies (anti-S100A8, -S100A9, -myeloperoxidase (MPO), -Collagen1, -CD68) (Santa Cruz Biotechnology, Inc., Santa Cruz, CA, USA), diluted 1:100-1:200, rinsed with TBS-T followed by incubation with secondary antibodies (different origin - depend on primary Abs) IgG peroxidase conjugate (Santa Cruz Biotechnology, Inc.), diluted 1:200 during $30 \mathrm{~min}$ at RT. Each incubation step was followed by $5 \mathrm{~min}$ rinses in TBS. To visualize the primary antibody binding sites, sections were incubated for $30 \mathrm{~min}$ in a solution of $0.05 \%$ AEC and $0.015 \%$ hydrogen peroxide, dissolved in PBS. As a negative control for the immunohistochemical reaction, sections were processed as described above except that the primary antibody was omitted. They were counterstained with Mayer's hematoxylin.

Immunofluorescent staining of AVs. Antibodies to S100A8 (1:50 dilution, sc-48352, Santa Cruz, CA), S100A9 (1:200 dilution, sc-20173, Santa Cruz, CA) were used. VICs grown in complete medium on glass coverslips were fixed in $10 \%$ neutral buffered formalin and permeabilized with Tween 20. Following fixation, the cells were blocked with $3 \%$ bovine serum albumin (BSA) in PBS for 20 minutes at $37^{\circ} \mathrm{C}$, and then incubated overnight at $4{ }^{\circ} \mathrm{C}$ with primary antibody diluted in $3 \% \mathrm{BSA}$. The next day, cells were washed twice with PBS and blocked with $10 \%$ goat serum (for $\mathrm{S} 100 \mathrm{~A} 9$ ) or $10 \%$ rabbit serum (for S100A8) for 30 minutes at room temperature. AlexaFluor 568 secondary antibodies $(10 \mu \mathrm{g} / \mathrm{mL}, \mathrm{A} 11011, \mathrm{~A} 11004$, and A11079, Invitrogen, Burlington, ON) diluted in $10 \%$ goat or rabbit serum e then they were applied for 30 minutes at room temperature. The cell nuclei were counterstained with DAPI. Fluorescent images were acquired on a Carl Zeiss microscope (Axio Imager A1).

Morphometric study. Evaluation of histochemical staining were carried out by counting the stained cells in the visual field with diameter of $1000 \mathrm{~mm}$ in morphometric program Pannoramic Viewer 1.15.4 (3DHistech).

Dot-Blot Analysis. The contents of S100A9 were evaluated by dot-blot assay involving primary antibodies to human S100A9 (rabbit polyclonal, sc-20173, 1 in 2000,
Santa Cruz, CA). Tissues were deparaffinized and rehydrated according to the protocol. Tissues were frozen, at $-80^{\circ} \mathrm{C}$, and thawed, and sonicated afterwards. Whole cell extract was mixed then with $2 \times$ Laemmli containing $\beta$-mercaptoethanol buffer and boiled at $100^{\circ} \mathrm{C}$ for 10 minutes and cooled down afterwards. Samples were then centrifuged to spin down crude cell debris. $50 \mu \mathrm{l}$ drop from each sample was applied to the membrane then drops were let to dry and membrane was blocked in 5\% skimmed milk solved in washing, PBS-T buffer, overnight at $4{ }^{\circ} \mathrm{C}$.

S100A9 was detected by the primary rabbit antibodies, dilution 1:2000 in 1\% skimmed milk solved in washing buffer. Immunodot was detected protein was the visualized by secondary goat anti-rabbit antibodies in the dilution $1: 10000$ in $1 \%$ solved in washing, PBS-T buffer. Then membrane was dried and scanned at for luminescence excited at $\lambda=800 \mu \mathrm{m}$.

Statistical analysis. Data was checked for normality (ND) by Shapiro-Wilk test. Most datasets showed non-normal distribution thus, non-parametric Mann-Whitney U-test was used to evaluate statistical significance. The correlation was assessed by Spearman Rank test.

\section{Research results}

Macroscopic and histological features of mineralized heart valves were described by us previously [9]. It should be noted that all CAVs had the signs of atherosclerotic process, emphasizing the obvious connection between CAV with atherocalcinosis.

The deposition of calcium compounds in CAV was in the form of gross deposits, and in the form of small grains, crumbs, which encrusted connective tissue fibers. Affected valves were characterized by the presence of sclerosis and hyalinosis of tissue, focal lipid deposition, edema, myxomatous changes, thickening of elastic and collagen fibers. This was especially typical for collagen type I, which manifests the highest tendency to calcification (Fig. 1A) [10]. Important histopathological change in CAV was the mixed cell inflammatory infiltration by the cells of macrophage series (histiocytes, macrophages - CD68-positive cells, Fig. 1B) and neutrophils (MPO-positive cells, Fig. 1C).

Immunohistochemical study of calgranulin A(S100A8) expression in CAV tissue shows the focal expression in the cells of the inflammatory infiltrate, substantial extracellular expression was not found (Fig. 1E). Studying of the calgranulin B (S100A9) distribution shows its great expression in the calcific aortic valves tissue extracellularly and intracellularly in the most resident valve cells and in circulating inflammatory cells (Fig. 1F). During IHC study of CAV tissue with fluorescent antibodies to S100A8 (Alexa 488, cyan-green color) and S100A9 (Alexa 555, yellow-green) co-localization of these molecules in calprotectin complex stained cytoplasm of S100A8 / S100A9 cells in orange color (Fig. 1D).

Research of apoptotic activity in CAV tissues, which was conducted by the expression level studying of apoptosis marker Caspase 3, showed its moderate expression in cells of AV tissues (Fig. 1G). OPN expression is evident in most CAV cells and extracellularly. Also intense deposition of this protein is observed in biomineralization parts (Fig. 1H). 
Aortic valves of control group had the signs of early (uncomplicated) stages of the atherosclerotic process, but without the process of biomineralization. AV tissue contained a significant number of interstitial cells (fibroblasts, smooth muscle cells (SMC), myofibroblasts and endothelial cells), among which small accumulation of circulating inflammatory cells (macrophages, lymphocytes, mast cells) is detected (Fig. 2A). Restructuring of the connective tissue was observed in the form of multiple sclerosis in the extracellular matrix of some AV samples of the control group. Also among the cellular elements of valves a small number of cardiomyocytes is revealed, they tend to the nonspecific staining by chromogen (mainly diaminobenzidine, for $\mathrm{AEC}$ it is not typical) during the immunohistochemical studies.

Medium correlation is found between age of the patients and calcification of the valves, $c=0.36, p=0.02$. No correlation between the calcification of the valves and sex is found.

During the immunohistochemical identification of
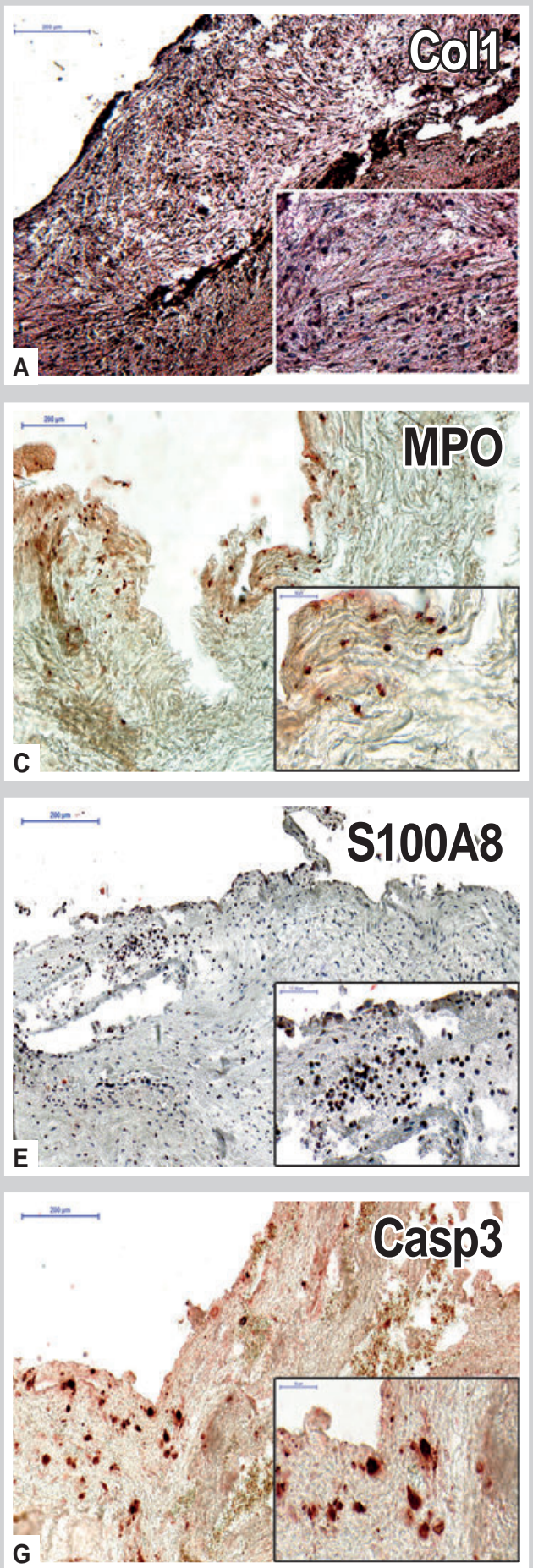
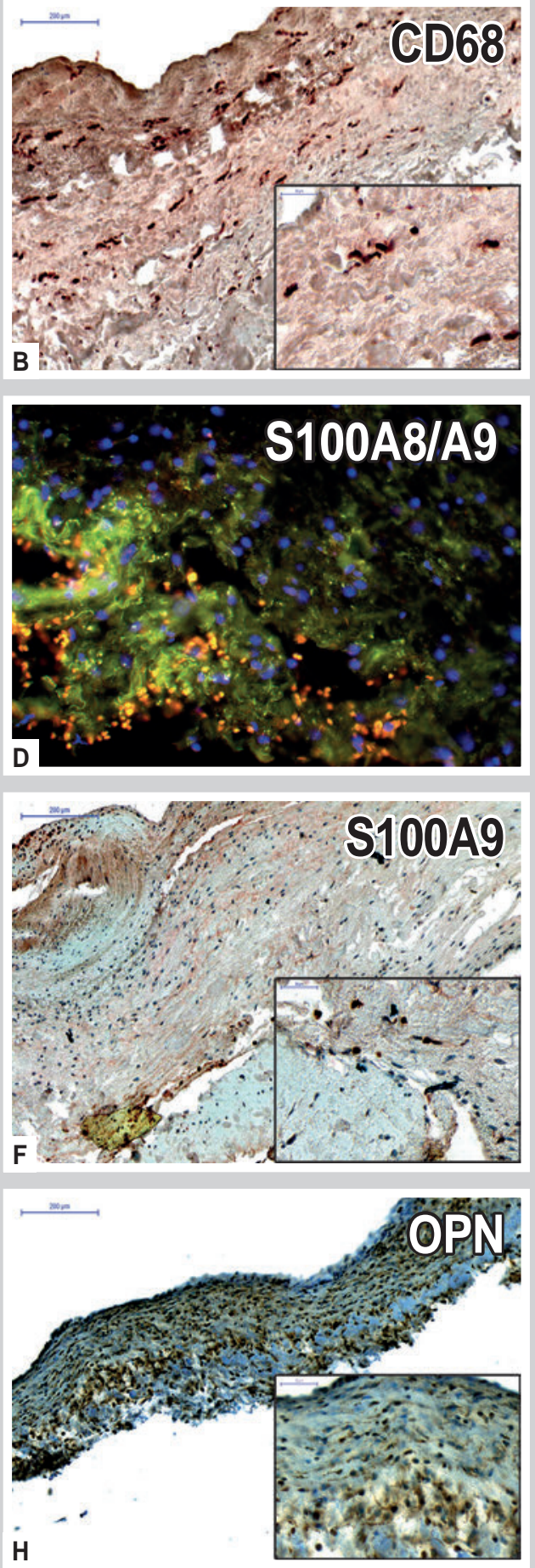

(A): Immunoreactivity of CAV tissue with antibodies to collagen type I, $\mathrm{DAB}$ chromogen, additional staining of nucleus by Mayer's hematoxylin.

(B): Immunohistochemical determination of CD68+ cells, AEC chromogen.

(C): Immunoreactivity of CAV tissue with antibodies to MPO, AEC chromogen

(D): Immunoreactivity of CAV tissue with antibodies to S100A8 and S100A9 co-localized as calprotectin. Blue - dapi, cyan-green color - Alex 488 (S100A8), yellow-green - Alexa 555 (S100A9), orange - calprotectin S100A8/A9. Magnification $\times 200$.

(E): Immunohistochemical expression of S100A8, AEC chromogen.

(F): Immunohistochemical expression of S100A9, AEC chromogen additional staining of nucleus by Mayer's hematoxylin.

(G): IHC expression of Caspase-3, AEC chromogen

(H): Immunohistochemical analysis of CAV tissue with OPN antibodies and Mayer's hematoxylin. Scale bar corresponds to $200 \mathrm{mcm}$, scale bar in insets $50 \mathrm{mcm}$.

Fig. 1. Immunohistochemical analysis of the leaflet tissues of calcific aortic valves. 
CD68+ cells in the tissue of control AVs it was found, that their number was not significantly different from the indices of the CAV group ( $p>0.05$ ) (Fig. 2B). On the other hand, CAVs contain much more MPO+-cells $(p<0.001)$ (Fig. 2C). During the study of the expression of heterodimer S100A8/S100A9 using fluorescent antibody it was noticed, that incidences of co-localization of these proteins in the form of a single complex was significantly lower in the control group than in the CAV group (Fig. 2D). However, the expression level of S100A8 is expressed moderately in the tissue of control AVs, mainly in the interstitial cells, it is not significantly different from the valve samples with biomineralization ( $p>0.05$ ) (Fig. $2 E$ ). AV of the control group demonstrate significantly lower expression level of S100A9 in the cell component of the tissue and also extracellularly $(p<0.01)$ (Fig. 2F).

This also concerns to the expression of the apoptosis marker Casp3 $(p<0.05)$ and mineralization marker OPN $(p<0.001)$, their levels are significantly lower in the control group (Fig. 2G, H).
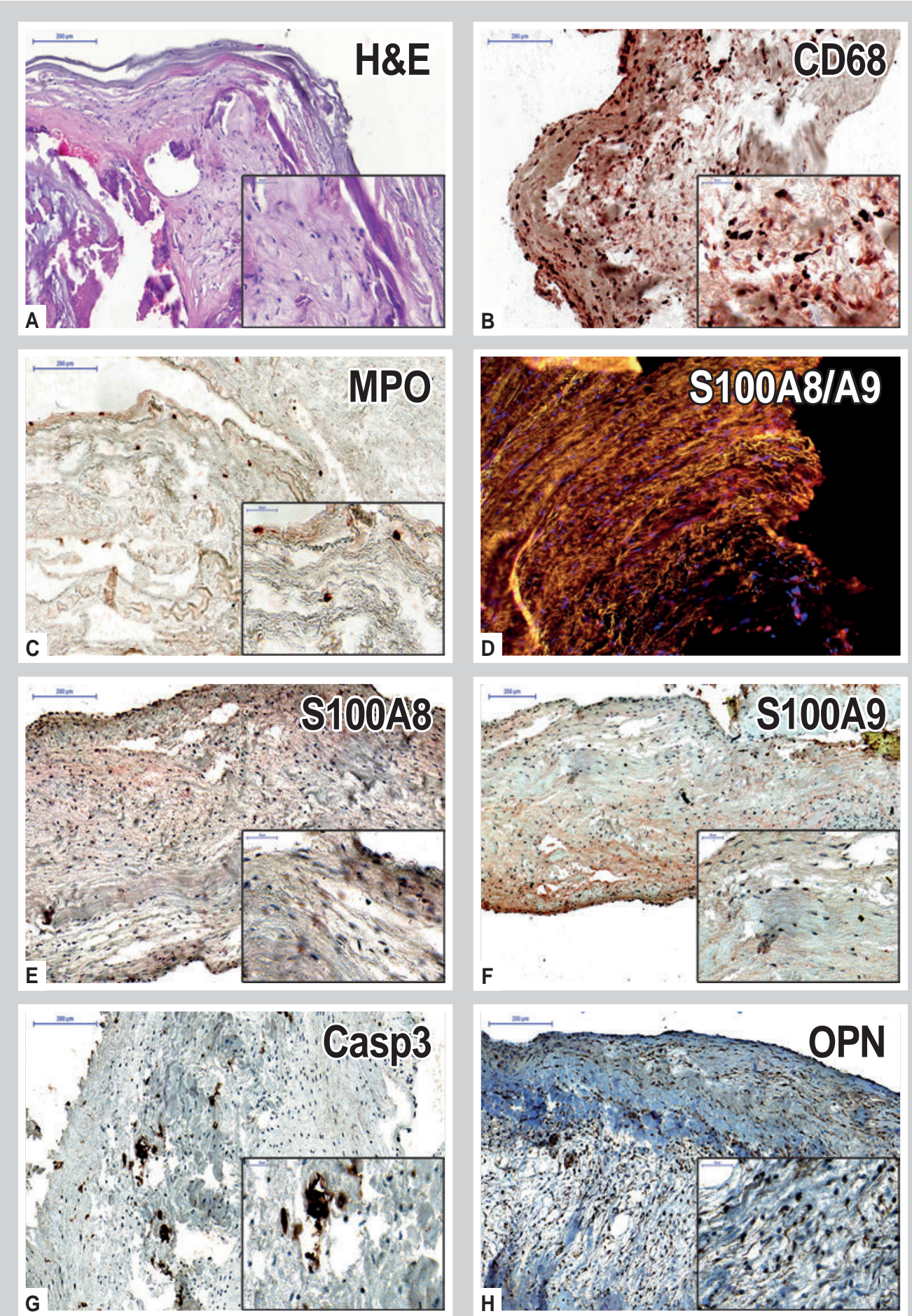
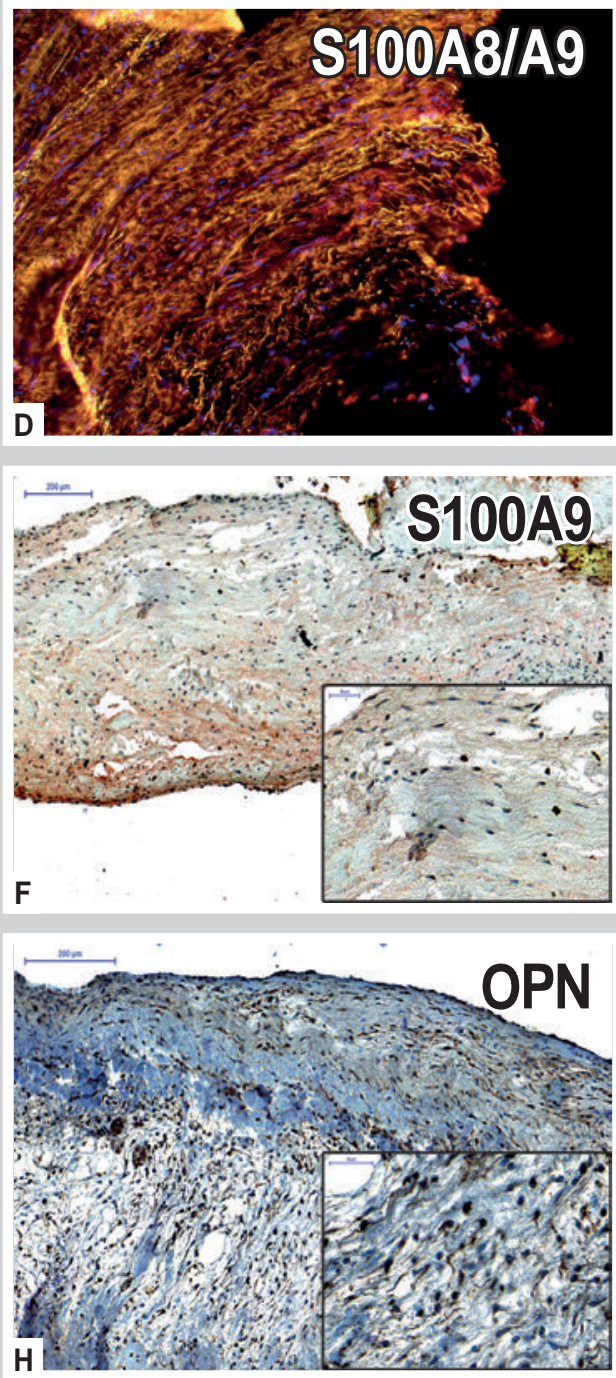

(A): Aortic valve with signs of atherosclerosis, hematoxylin-eosin staining.

(B): Immunohistochemical determination of CD68+ cells, AEC chromogen.

(C): Immunoreactivity of AV tissue with antibodies to MPO, AEC chromogen.

(D): Immunoreactivity of AV tissue with antibodies to S100A8 and S100A9 co-localized as calprotectin. Blue - dapi, cyan-green color - Alex 488 (S100A8), yellow-green - Alexa 555 (S100A9), orange - calprotectin S100A8/A9. Magnification x100.

(E): Immunohistochemical expression of S100A8, AEC chromogen.

(F): Immunohistochemical expression of S100A9, AEC chromogen, additional staining of nucleus by Mayer's hematoxylin.

(G): IHC expression of Caspase-3, AEC chromogen, additional staining of nucleus by Mayer's hematoxylin.

(H): Immunohistochemical analysis of AV tissue with OPN antibodies and Mayer's hematoxylin.

Scale bar $200 \mathrm{mcm}$, scale bar in insets $50 \mathrm{mcm}$.

Fig. 2. Immunohistochemical analysis of leaflet tissues of aortic valves without biomineralization. 


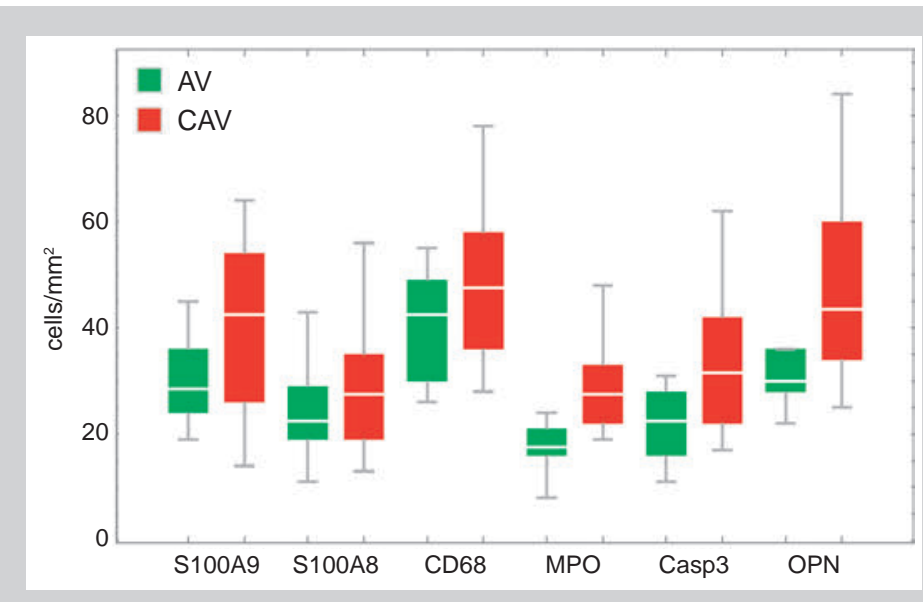

Fig 3. Median numbers of immuno-positive cells for AV and CAV groups.

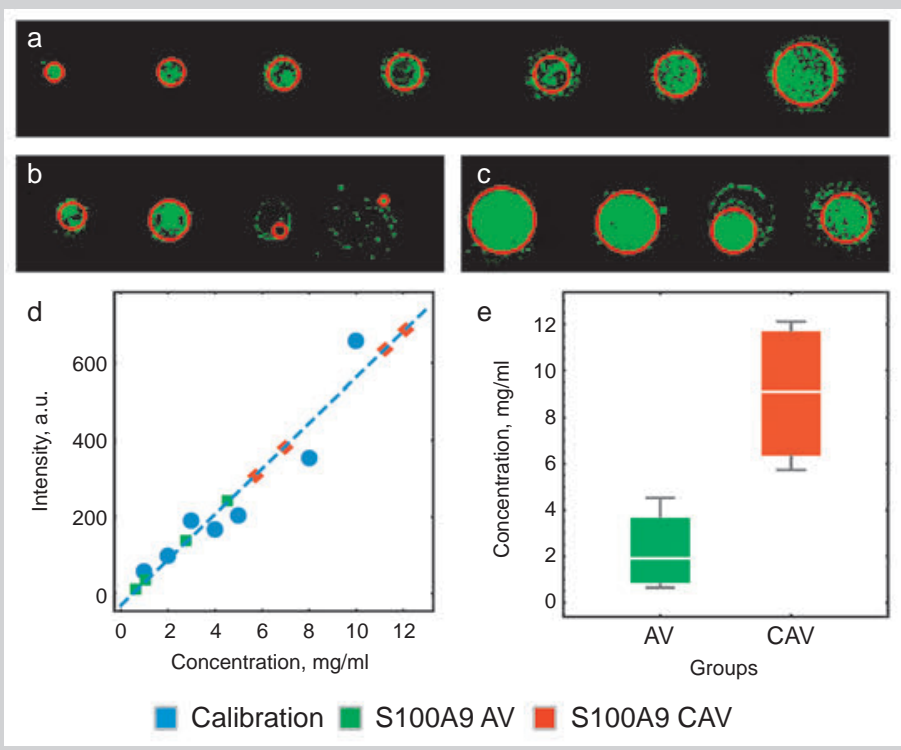

Fig. 4. Dot-blot analysis of S100A9 in aortic valve tissues; (a): calibration fluorescence dots; (b): AV group fluorescence dots; (c): CAV group fluorescence dots; (d): calibration curve; (e): comparison between concentration of S100A9 in AV and CAV groups $(p=0.01)$. Red circles in dot fluorescence images represent effective circles derived from the fluorescence of dots, shown for illustration purposes only.

\section{Discussion}

Pathological biomineralization of heart valves causes the deep morphological and functional restructuring of all tissue components. The quantitative and qualitative composition of valve interstitial cells (VICs), fibrillar component (collagen and elastin) changes, valve endothelial cells (VECs) are affected adversely. Endothelial cells, that cover the surface and cooperate closely with valve interstitial cells, guarantee the integrity of the valve tissue [11]. Their damage is a critical event in the aortic valves pathology [12]. Necessary conditions for VECs affecting are created in the case of atherosclerosis: lipid infiltration, plaque and detritus formation, infiltration by circulating inflammatory cells (CICs) [12]. It is known, that circulating inflammatory cells (macrophages, lymphocytes, neutrophils, plasma cells) secret calgranulin A and B, which in turn can form calprotectin complex (heterodimer)
S100A8/S100A9. This complex possesses a cytotoxic activity if expressed in high amounts [13]. Cytotoxicity mechanism of calprotectin is the sequestration of divalent cations, particularly zinc and manganese, consequently leading to decrease in the efficiency of antioxidant system and further induction of apoptosis.

Majority of the tissues from the CAV group contained both S100A8 and S100A9 as shown by fluorescence immunohistochemistry in (Fig. 3). The colocalization of these two staining patterns points on the presence of calprotectin complex in the tissues of CAV group. The staining pattern of S100A8/A9 in the tissues of AV group was comparable with the background staining (not shown) demonstrating that the expression of these proteins is much higher in the tissues of CAV group. Total concentration of S100A9 protein, which has much higher cytotoxic activity, in the tissues of 4 patients from CAV group was significantly higher $(p=0.01)$ than in the tissues of 4 patients from AV group (Fig. 4).

Apart from its cytotoxic activity S100A9 is also a proinflammatory cytokine, therefore under prolonged inflammatory conditions it can serve as a positive feedback in induced apoptosis of VECs and VICs (involving the mitochondrial way, caspase-3 and caspase-9) and to the less extent of necrosis [13]. Indeed, in our study the expression score for apoptotic caspase-3 marker for the patients of CAV group is significantly higher $(p<0.01)$ than in AV group. Morphologically, this process is manifested by the detachment and desquamation of the endothelium and deep damage of the valve leaflets.

It is believed that proinflamatory cytokine role of S100A8/A9 proteins is connected with the activation of toll-like receptors, shown to exist in the membranes of VECs, fibroblasts and inflammatory cells [6,7]. Activation of these receptors (RAGE, TLR-4) accelerates vascular biomineralization both in vitro, and in vivo [14]. Thus, based on our results we can speculate that calprotectin-induced apoptosis, sustained under chronic inflammation can be a critical element in the progression of vascular biomineralization and atherosclerosis.

OPN expression in aortic valves has been explored in several recent studies $[15,16]$ demonstrating that expression of OPN is related to biomineralization. In line with these studies, our research demonstrates an increased expression of OPN in the tissues of CAV group - both extracellularly and in valve cells (interstitial and circulating). Apart from intra/extra cellular localizations significant amounts of OPN were found in biomineral deposits, demonstrating that one of the major roles of OPN is the blocking of hydroxyapatite crystals growth by binding to crystal surfaces preventing the spread of biomineralization [17].

Osteopontin and calgranulin B are synthesized and secreted by the same cells, neutrophils and macrophages play the main role among them. In the case of IHD studied $\mathrm{CD} 8^{+}$cells were detected with approximately equal frequency in both groups $(p>0.05)$, but the number of neutrophils in CAV was significantly higher than its number in the control group. In fact, this means that calgranulin has cytotoxicity and damage of AV tissues is realized by neutrophils. As calgranulin A and B form about $45 \%$ of cytoplasmic proteins of neutrophils, this is easily combined with a high concentration of calgranulin B in CAV [18]. 
The inflammatory process in the AVs leads to the changes in the extracellular matrix of their tissues, to the imbalance between local pro- and anti-calcium mechanisms, which create favorable conditions for the mineral deposition. For example, in CAV tissue collagen type I supports the osteogenic differentiation of SMC, those number increases in the valves from 5 to $30 \%$ under pathological conditions. Valve interstitial cells, which cooperate with collagen type I, remain to be in a "quiet" state for a long time, but they show myofibroblastic phenotype and form quickly a calcium units during the appearance of fibrin (which obligatory arises in the case of atherosclerotic plaque development) [19].

Under the influence of damaging factors its desquamation and exposure of connective tissue matrix arise (Fig. 1A). Cell death promotes the release of a great amount of inorganic phosphate and calcium. Thus, a significant amount of building material and the presence of connective tissue matrix (collagen type I) create the conditions for the development of pathological biomineralization.

\section{Conclusions}

Our data shows a significant increase of calgranulin and OPN expression in mineralized tissue of AV $(p<0.01)$. The higher expression level of Casp3 was also found in CAV $(p<0.05)$.

Comparing the first and second series of samples, connection between the expression of calgranulin $A$, saturation of tissues with CD68+ cells (macrophages) were not found. However, the number of neutrophils in CAVs was higher than in the control group, indicating the leading role of neutrophil inflammatory infiltration in tissue damage of AVs (Fig. 5).

The results show the regulatory role of calgranulin $B$ and OPN in the development of PBM.

\section{References}

[1] lung, B., Baron, G., Butchart, E. G., Delahaye, F., Gohlke-Bärwolf, C., Levang, O. W. et al. (2003) A prospective survey of patients with valvular heart disease in Europe: The Euro Heart Survey on Valvular Heart Disease. Eur Heart J, 24, 1231-43. doi: https://doi.org/10.1016/ S0195-668X(03)00201-X.

[2] The task force on the management of valvular hearth disease of European Society of Cardiology (2007). Guidelines on the management of valvular heath disease.

[3] Tornos, P. (2006) Valvular hearth disease in women. Rev Esp Cardiol, 59, 832-6.

[4] Palorari, A., Loardi, C., Mussoni, L., Cavallotti, L., Camera, M., Biglioli, P., et al. (2009) Nonrheumatic calcific aortic stenosis: an overview from basic science to pharmacological prevention. European Journal of Cardio-thoracic Surgery, 35, 493-504. doi: 10.1016/j.ejcts.2008.11.033.

[5] Dzemeshkevich, S. L., Stivenson, L. W., \& Alexi-Meschischvili, V. V. (2004) Bolezni aortal'nogo klapana: funccia, diagnostika, lecheniye [Diseases of the aortic valve: function, diagnosis, treatment]. Moscow: Geotar-Med. [in Russian].

[6] Yang, X., Fullerton, D. A., Su, X., , Ao, L., Cleveland, J. C. Jr., \& Meng, X (2009) Pro-osteogenic phenotype of human aortic valve interstitial cells is associated with higher levels of Toll-like receptors 2 and 4 and enhanced expression of bone morphogenetic protein 2. J. Am. Coll. Cardiol, 53(6), 491-500. doi: 10.1016/j.jacc.2008.09.052.

[7] Vogl, T., Gharibyan, A., \& Morozova-Roche, L. A. (2012) Pro-inflammatory S100A8 and S100A9 proteins: self-assembly into multifunctional native and amyloid complexes. Int. J. Mol. Sci, 13, 2893-2917. doi: 10.3390/ijms13032893.

[8] Sainger, R., Grau, J. B., Poggio, P., Branchetti, E., Bavaria, J. E., Gorman, J. H. et al. (2012) Dephosphorilation of circulating human osteopontin correlates with severe vascular calcification in patients with calcific aortic valve disease. Biomarkers, 17(2), 111-8. doi: 10.3109/1 354750X.2011.642407.

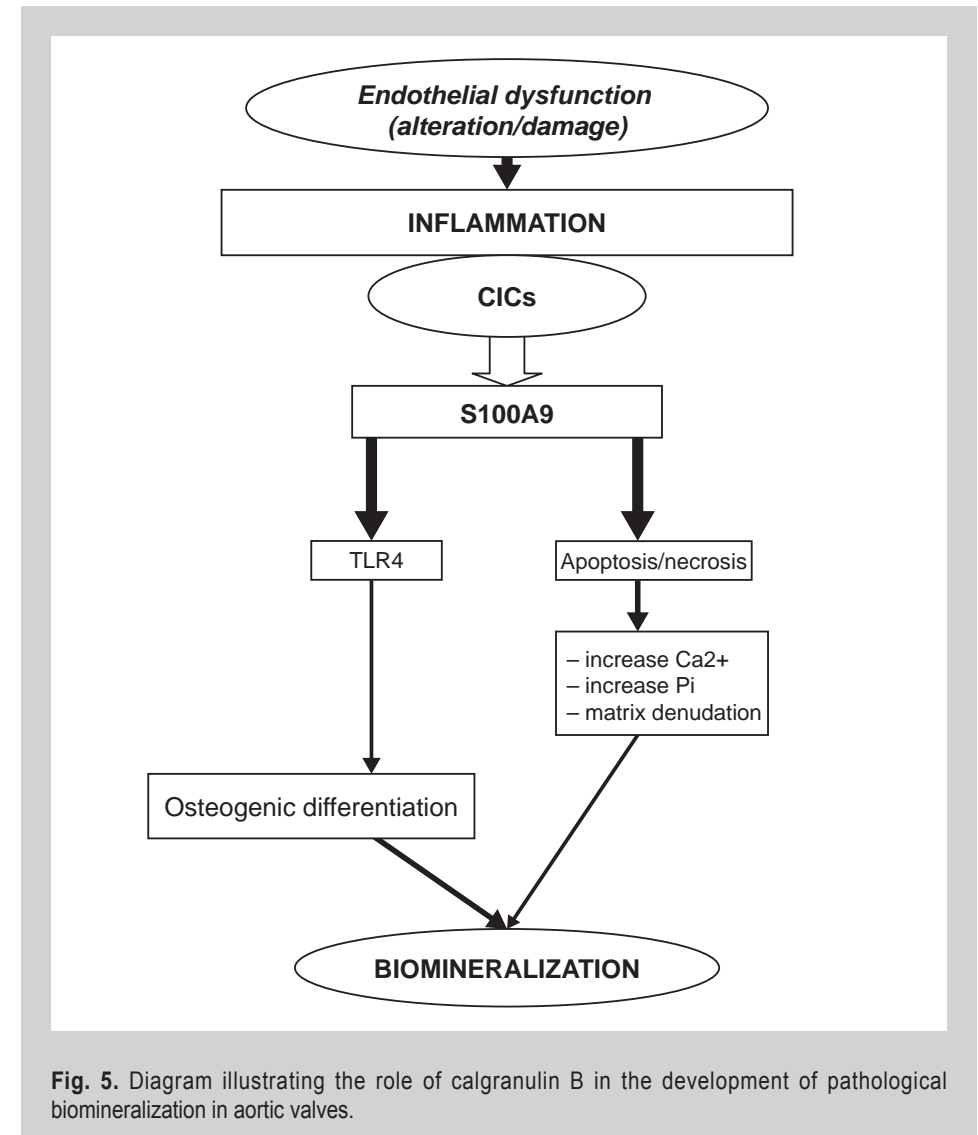

[9] Moskalenko, R., Romaniuk, A., Zakorko, I-M., Levchenko, D. O. Piddubnyi, A. M., \& Hetmanska, V. M. et al. (2016) Pathological biomineralization in heart valves affected by atherosclerosis. J. Clin. Exp. Med. Res, 4(4), 564-571.

[10] Hamlin, N. J., \& Price, P. A. (2004) Mineralization of decalcified bone occurs under cell culture conditions and requires bovine serum but not cells. Calcif Tissue Int, 75(3), 231-42. doi: 10.1007/s00223-004-0190-1.

[11] Butcher, J. T., \& Mahler, G. J. (2006) Inflammatory regulation of valvular remodeling: the good (?), the bad, and the ugly. J. Tissue. Eng, 12(7), 905-915.

[12] Miller, J. D., Weiss, R. M., \& Heistad, D. D. (2006) Calcific aortic valve stenosis: methods, models, and mechanisms. Circ Res, 108, 1392-1412, doi: 10.1161/CIRCRESAHA.110.234138.

[13] Damo, S. M., Kehl-Fie, T. E., Sugitani, N., Holt, M. E., Rathi, S., Murphy, W. J., et al. (2013) Molecular basis for manganese sequestration by calprotectin and roles in the innate immune response to invading bacterial pathogens. PNAS, 110(10), 3841-3846. doi: 10.1073/pnas.1220341110.

[14] Franke, S., Rüster, C., Pester, J., Hofmann, G., Oelzner, P., \& Wolf, G. (2011) Advanced glycation end products affect growth and function of osteoblasts. Clin Exp Rheumatol, 29(4), 650-60.

[15] Grau, J. B., Poggio, P., Sainger, R., Vernick, W. J., Seefried, W. F., Branchetti, E., et al. (2012) Analysis of osteopontin levels for the identification of asymptomatic patients with calcific aortic valve disease. Ann Thorac Surg, 93, 79-86. doi: 10.1016/j.athoracsur.2011.08.036.

[16] Passmore, M., Nataatmadja, M., Fung, Y. L., Pearse, B., Gabriel, S., Tesar, P., \& Fraser, J. F. (2015) Osteopontin alters endothelial and valvular interstitial cell behavior in calcific aortic valve stenosis through HMGB1 regulation. Eur J Cardiothorac Surg, 48, e20-e29. doi: 10.1093/ ejcts/ezv244.

[17] Steitz, S. A., Speer, M. Y., McKee, M. D. et al. (2002) Osteopontin inhibits mineral deposition and promotes regression of ectopic calcification. Am. J. Pathol, 161(6), 2035-46. doi: 10.1016/S0002-9440(10)64482-3.

[18] Edgeworth, J., Gorman, M., Bennett, R., Freemont, P., \& Hogg, N. (1991) Identification of $p 8,14$ as a highly abundant heterodimeric calcium binding protein complex of myeloid cells. Journal of Biological Chemistry, 266(12), 7706-7713.

[19] Chen, J. H., Chen, W. L., Sider, K. L., Yip, C. Y., \& Simmons, C. A (2011) $\beta$-catenin mediates mechanically regulated, transforming growth factor- $\beta 1$-induced myofibroblast differentiation of aortic valve interstitial cells. Arterioscler Thromb Vasc Biol, 31(3), 590-7. doi: 10.1161/ATVBAHA.110.220061. 
Information about authors:

Moskalenko R. A., MD, PhD, Associate Professor, Department

of Pathology, Sumy State University, Ukraine.

Romaniuk A. M., MD, PhD, DSc, Professor, Head of the Department

of Pathology, Sumy State University, Ukraine.

lashchishyn I. O., PhD, Assistance Professor, Department

of General Chemistry, Sumy State University, Ukraine; Postdoctoral

position at the Department of Medical Chemistry, Biochemistry

and Biophysics, Umeå University, SE-90187, Sweden.

Zakorko I.-M. S., MD, PhD student, Department of Pathology,

Sumy State University, Ukraine.

Piddubnyi A. M., MD, PhD student, Department of Pathology,

Sumy State University, Ukraine.

Chernov Ye. O., PhD student, Department of Medical Chemistry,

Biochemistry and Biophysics, Umeå University, SE-90187, Sweden.

Morozova-Roche L. O., DSc, prof, Department of Medical

Chemistry, Biochemistry and Biophysics, Umeå University,

SE-90187, Sweden.

Відомості про авторів:

Москаленко Р. А., канд. меА. наук, Аоцент каф. патологічної анатомії, Аокторант, Сумський Аержавний університет, Україна. Романюк А. М., А-р меА. наук, професор, зав. каф. патологічної анатомії, Сумський державний університет, Україна.

Ящишин І. О., канА. фіз.-мат. наук, асистент каф. загальної хімії, Сумський державний університет, Україна; постАок на каф. медичної хімії, біохімії і біофізики, Університет Умео, Швеція.

Закорко І.-М. С., аспірант каф. патологічної анатомії, Сумський державний університет, Україна.

Підаубний А. М., аспірант каф. патологічної анатомії, Сумський Аержавний університет, Україна.

Чернов Є. О., аспірант каф. медичної хімії, біохімії і біофізики, Університет Умео, Швеція.

Морозова-Роше ^. О., А-р фіз.-мат. наук, професор каф.

медичної хімії, біохімії і біофізики, Університет Умео, Швеція.

\section{Сведения об авторах:}

Москаленко Р. А., канА. мед. наук, Аоцент каф. патологической анатомии, Аокторант, Сумский государственный университет, Украина.

Романюк А. Н., А-р меА. наук, профессор,

зав. каф. патологической анатомии, Сумский госуАарственный университет, Украина.

Ящишин И. А., канА. физ.-мат. наук, ассистент каф. общей химии, Сумский государственный университет, Украина; постАок на каф. меАицинской химии, биохимии и биофизики, Университет Умео, Швеция.

Закорко И.-М. С., аспирант каф. патологической анатомии, Сумский государственный университет, Украина.

ПиААубный А. М., аспирант каф. патологической анатомии, Сумский государственный университет, Украина.

Чернов Е. А., аспирант каф. медицинской химии, биохимии и биофизики, Университет Умео, Швеция.

Морозова-Роше $\Lambda$. А., А-р физ.-мат. наук, профессор

каф. медицинской химии, биохимии и биофизики, Университет Умео, Швеция.

Конфмікт інтересів: відсутній.

Conflicts of Interest: authors have no conflict of interest to declare.

Financial support. The work was supported by the research theme "The study of changes in the bones in the presence of fractures using nanomaterials for metal osteosynthesis, considering a function of muscular system " (state registration number 0116U006815), state budget theme "Morphofunctional monitoring of organs andsystems under the conditions of homeostasis disorders", state registration - № 62.20.02-01.15/17.GF and FP-7 Marie Curie Action "Nano-Guard" 269138. 